Aleksandra Burba

Uniwersytet Jagielloński

\title{
KULTUROTWÓRCZA ROLA TŁUMACZY POEZJI ZBIGNIEWA HERBERTA NA JĘZYK NIEMIECKI NA PRZYKŁADZIE KORESPONDENCJI POETY \\ Z HEINRICHEM KUNSTMANNEM ORAZ PROGRAMU TRANSLATORSKIEGO KARLA DEDECIUSA, W ODNIESIENIU DO MYŚLI HERMENEUTYCZNEJ HANSA-GEORGA GADAMERA - ZARYS PROBLEMATYKI
}

Zarys treści: W artykule opisano proces „osiedlania się” poezji Zbigniewa Herberta na niemieckim obszarze językowym i kulturowym za sprawą przekładów tej poezji na język niemiecki, głównie na przykładzie tłumaczeń dokonanych przez Karla Dedeciusa, będących częścią szerszego programu translatorskiego i kulturalnego tego tłumacza. W tekście znajduje się także odwołanie do korespondencji poety z Heinrichem Kunstmannem. Autotematyczne wypowiedzi Karla Dedeciusa na temat procesu translacji, jej założeń i celów, czytane są przy tym w kontekście hermeneutycznym, zwłaszcza w odwołaniu do prac Hansa-Georga Gadamera. Wywód zilustrowano końcową szkicową interpretacją przekładu wiersza Herberta U wrót doliny zestawionego z przekładem Przesłuchania anioła.

Słowa kluczowe: tłumaczenie poezji; przekład literacki; hermeneutyka

Bardzo chciałbym, aby Pan lubił ten naród. Serdeczny stosunek z Panem jest dlatego dla mnie drogi, że ponad tym szerokim rowem krzywd, krwi i głupoty pleciemy naszą nitkę porozumienia.

Zbigniew Herbert w liście do Heinricha Kunstmanna (Herbert 2012: 45, list z 27 grudnia 1959 r.) 
Literaturę można porównać do okna, przez które jeden naród patrzy drugiemu w oczy, które ułatwia postronnym wgląd w środowisko życiowe danego kraju. Karl Dedecius, Tradycja, która nas przybliża

(Dedecius 1996: 123)

O ambiwalentnym stosunku Zbigniewa Herberta do krajów niemieckojęzycznych, w których przecież nierzadko przebywał, świadczą niektóre fragmenty jego korespondencji z Czesławem Miłoszem (Zarychta 2011). Można jednak znaleźć i cieplejsze słowa Herberta na temat relacji polsko-niemieckich, choćby w listach do tłumacza jego dramatów na język niemiecki Heinricha Kunstmanna, w których odnajdujemy istotny fragment wybrany przeze mnie na motto niniejszego szkicu - „ponad tym szerokim rowem krzywd, krwi i głupoty pleciemy naszą nitkę porozumienia”. Drugim mottem stały się słowa Karla Dedeciusa, najbardziej rozpoznawalnego w Niemczech i w Polsce tłumacza dorobku Herberta na język Goethego. Te dwa cytaty dwóch różnych, a dodatkowo konkurujących ze sobą o Herberta tłumaczy ${ }^{1}$, wybrane zostały nie bez przyczyny. Są bowiem niby dwa brzegi rzeki, które łączy most, lub też jak dwa przęsła owego mostu. $Z$ jednej strony widać pragnienie porozumienia po stronie poety, a z drugiej - po stronie tłumacza. Co istotne, porozumienia na płaszczyźnie szerszej niż tylko dokonanie dobrego przekładu utworów.

Niniejszy tekst jest poszukiwaniem wstępnych odpowiedzi na pytanie, w jaki sposób poezja Zbigniewa Herberta zaistniała na niemieckim obszarze językowym za sprawą jej tłumaczeń. Mając świadomość dotychczasowych prac, zarówno polskich, jak i niemieckich badaczy ${ }^{2}$, warto dokładniej, w charakterze preludium do dalszych pogłębionych badań, przyjrzeć się mo-

${ }^{1}$ „A teraz zdaje się, że Herbert całkiem już poślubił pana Dedeciusa; w każdym razie już od dłuższego czasu mieszka u niego we Frankfurcie. Po ludzku rzecz biorąc, rozczarował mnie. Przed dziesięciu laty spopularyzowałem tu jego słuchowiska, zawsze wskazując przy tym na jego poezję. Potem umarł Lec i Dedecius potrzebował nowego człowieka. Znalazł go w Herbercie, który okazał się za miękki i za słaby, aby oprzeć się jego objęciom. No dobrze, niech robi jak chce" - List H. Kunstmanna z 15 lutego 1968 r. do Rudolfa Richtera, cyt. za: Herbert 2012: 41. Z korespondencji tej wynika jednocześnie, że Kunstmann uzyskiwał od Herberta cenne rady dotyczące polskich znaczeń poszczególnych słów, $\mathrm{z}$ kolei tłumacz służył jako pośrednik także w tym sensie, że przekazywał poecie „zamówione” przez niego listownie niemieckie książki, np. tomiki Gottfrieda Benna.

2 M.in. Antoniuk 2010, Dedecius 1989, Heydel 2010, Krasoń 2007, Rosinek 1995, Schulze 2010, Zarychta 2010. 
tywacjom, celom i efektom prac przekładowych, a także samemu procesowi przekładu. Ważnym kontekstem metodologicznym będzie przy tym, choć nie wyłącznie, ujęcie hermeneutyczne, a podstawowe tezy zilustrowane zostaną autotematycznymi wypowiedziami Karla Dedeciusa, zgodnymi ze słowami Hansa-Georga Gadamera, zwłaszcza wtedy, gdy ten ostatni porównuje tajemnicę czytania do mostu rozpiętego pomiędzy językami:

Czytanie jest jak przeprawa z jednego brzegu na drugi, odległy, i tak samo czynność tłumacza tekstu jest przeprawą z brzegu na brzeg, z jednego lądu na drugi, z tekstu na tekst [...]. Powinniśmy podziwiać wszystkich tłumaczy, którzy nie ukrywają przed nami dystansu, jaki dzieli przekład od oryginału, a zarazem przerzucają nad nimi most. Są interpretatorami. [...]. Ale są jeszcze czymś więcej. [...] tekst tłumacza współtworzy szlak wszelkiej naszej lektury i rozumienia. [...] Jest jak most, na który można wejść z obu stron, most między dwoma brzegami w jednym kraju (Gadamer 2009: s. 324-325).

Dedecius w swoich przekładowych szkicach nie powołuje się wprawdzie wprost na hermeneutów, na Martina Heideggera czy Gadamera, wiele podstawowych założeń wyraża jednak w sposób bliski hermeneutyce ${ }^{3}$. Przede wszystkim często posługuje się figurą tłumaczenia jako mostu oraz tłumacza jako przewoźnika lub pośrednika. Rolę tego ostatniego podkreśla zaś zwłaszcza wobec trudnych polsko-niemieckich relacji, które wymagały wzajemnej ufności w celu umożliwienia kulturowego transferu. „Sensem tej przygody [...] jest służba: służba przewoźnika, służenie komunikacji między światami, budowanie żywego pomostu między dwoma brzegami jednej rzeki” - pisał Dedecius w Notatniku tłumacza (Dedecius 1974: 30).

Zgodnie z poglądami Heideggera na naturę języka mówienie powoduje swoiste oświetlanie przedmiotu nazywanego. Wypowiedzenie nazwy kieruje niejako światło na dany przedmiot obecny w rzeczywistości obiektywnej (Rymkiewicz 2002: 119-125). Ta cecha języka uwidacznia się w szczególny sposób w przekładzie, kiedy to tekst tłumaczony - nierzadko z konieczności - zawiera inne słowa (lub niektórych w ogóle nie zawiera) niż tekst wyjściowy. Tekst przekładu oświetla więc co do zasady nieco inny „obszar”. Jednym z głównych dzieł Heideggera zawierających refleksje nad językiem jest wybór

${ }^{3}$ W szkicu Wieland, Horacy i my. Wniebowzięcie filologii Dedecius odwołuje się do hermeneutyki jako takiej, ale nie do konkretnego myśliciela (Dedecius 2013: 233). W podobnym duchu pisze też w szkicach Przyswajanie obcości w przekładzie oraz Sztuka przekładu, w których stwierdza m.in., że zarówno czytanie, jak i mówienie są przekładaniem (Dedecius 2013: 243-272). 
rozpraw Unterwegs zur Sprache - W drodze do jezzyka, wydany w roku 1959 (Heidegger 2007). Zbiór ten, na który składają się m.in. rozprawy Język, Język $w$ poezji, Istota języka, ma dla filologa tym większą wartość, że rozważania filozofa dotykają żywej tkanki poezji, w tym głównie utworów Georga Trakla, ale też Friedricha Hölderlina czy Stefana Georgego. Znajdujemy tam (w rozważaniu o poezji Trakla) taki oto fragment:

Język poezji jest z istoty wieloznaczny, i to na swój sposób. Nic nie słyszymy z powiadania poezji, dopóki wychodzimy mu na przeciw z jakimkolwiek stłumionym znaczeniem jednoznacznego mniemania (Heidegger 2007: 66)

- z takiego charakteru języka poetyckiego wynika dla tłumacza poezji konieczność „podejścia do wiersza” z całym naręczem znaczeń i następnie wymóg dokonania wyboru tego znaczenia, którym posłuży się on dla oddania wiersza w języku docelowym. Nierzadko zawartość owego bukietu znaczeń, którym dysponuje tłumacz, będzie zależna od jego uwarunkowań kulturowych, często w nie wpisana. Oto słowa Karla Dedeciusa, analogiczne do wywodu cytowanego filozofa:

To, czy w konkretnym przypadku decydujemy się w przekładzie na tę lub inną formę, tę czy inną formację, zawsze ma wielkie znaczenie i swoje konsekwencje. Decyduje bowiem o tym, czy obca kultura stanie się we własnym języku tłumacza czymś swojskim, czy pozostanie obcym (Dedecius 2013: 246).

Jak pisze Heidegger, odnosząc się do języka jako „domu bycia” - „Jeżeli dzięki swojemu językowi człowiek mieszka $\mathrm{w}$ namowie bycia, to my, Europejczycy, mieszkamy zapewne w zupełnie innym domu niż człowiek Dalekiego Wschodu" (Heidegger 2007: 79). Także w ramach europejskiej rodziny domy te będą odmienne, i jest to dla tłumacza niejednokrotnie wielkim wyzwaniem.

Jako pierwszy w odniesieniu do twórczości Herberta podjął je w Niemczech pod koniec lat 50. ubiegłego stulecia Heinrich Kunstmann, tłumacz jego dramatów, a następnie, tłumaczący głównie poezję, Karl Dedecius. Ten ostatni spośród innych tłumaczy poezji Herberta na niemiecki wyróżnia się tym, że - jak wiadomo - uczynił tłumaczenie jego wierszy elementem szerszego programu kulturalnego: programu upowszechniania literatury polskiej, mającego na celu zbliżenie do siebie sąsiedzkich krajów dzięki wielokrotnie wskazywanym zależnościom historyczno-kulturowym, i to mimo trudnych doświadczeń z niedalekiej przeszłości. 
Pokrewieństwa założeń programu translatorskiego Dedeciusa $\mathrm{z}$ hermeneutyką doszukać się można m.in. w eseju Gadamera zatytułowanym Człowiek $i$ język, w którym autor wychodzi od ogólnej roli języka w życiu każdego człowieka i przechodzi następnie do skrótowego omówienia przekładu, twierdząc najpierw, że żaden z przekładów nie jest tak zrozumiały jak oryginał, a następnie, że - w konsekwencji - zadaniem tłumacza nie jest bynajmniej odtworzenie powiedzianego. „Musi on raczej zwrócić się w kierunku przez nie wskazanym, to znaczy ku jego sensowi, by przenieść to, co jest do powiedzenia, w perspektywę swego własnego mówienia" (Gadamer 2000: 61). Fragment ten pokazuje doskonale, że proces przekładu wymaga od tłumacza najpierw zabiegów interpretacyjnych (określenie tego, co jest do powiedzenia) i następnie przekazania tego nie tylko w języku docelowym, ale też w kulturze docelowej (czyli w perspektywie swego własnego mówienia). Dedecius opisał ten proces w następujący sposób:

Dwie istoty pochodzące $\mathrm{z}$ tego samego źródła, lecz o różnych właściwościach, przezwyciężają wzajemną obcość, stają się sobie bliskie, obdarzają się zaufaniem i tworzą istotę trzecią, potomstwo, które pozwala im przetrwać własną śmierć [...]. Tłumaczenie z języków obcych zmusza nas do rozważań, którym w normalnym przypadku, używając tylko mowy ojczystej, nie poświęcilibyśmy tyle uwagi. Poprzez zgłębianie ducha obcego języka odkrywamy dopiero właściwe piękno i możliwości mowy własnej (Dedecius 1996: 61).

W trzeciej części Prawdy i metody Gadamer pisze z kolei:

Tłumacz musi umieścić podlegający rozumieniu sens w kontekście, w którym dany uczestnik rozmowy żyje. [...] Sens ma zostać zachowany, ponieważ jednak ma być rozumiany w nowym świecie językowym, trzeba go w nowy sposób wyrazić. Dlatego każdy przekład jest już interpretacją, można nawet rzec, realizacją sensu, jaki tłumacz nadał przekazanemu mu słowu (Gadamer 2007: 520).

Od strony obcego języka pada inne, nowe światło, oświetlając czytelnikowi tekst. Wierność wymagana od tłumacza nie może usunąć zasadniczej odmienności języków. Nawet chąac wypełnić ten wymóg wierności, stajemy przed koniecznością trudnych decyzji. Gdy chcemy wydobyć w przekładzie jakiś ważny dla nas rys oryginału, możemy to uczynić tylko przez zaniedbanie innych rysów lub wręcz całkowite ich ukrycie. Takie właśnie postępowanie nazywamy interpretowaniem (Gadamer 2007: 522). 
O tyle własny horyzont interpretatora jest istotny, ale nie jako własne stanowisko, podtrzymywane i forsowane, lecz raczej jako pogląd i możliwość, wprowadzone do gry, wystawiane na ryzyko i pomagające w rzetelnym przyswojeniu sobie treści tekstu. (Gadamer 2007: 525).

Podsumowując, Gadamer stwierdza, że przez kolejne swoje rezygnacje tłumacz bierze na siebie swego rodzaju przejaskrawienie przekładu, który w efekcie „jest jaśniejszy i prostszy niż oryginał” (Gadamer 2007: 523)4. Warunkiem takiej rozmowy jest podejście do człowieka (lub też do historii, tradycji, przekazu), które nie uprzedmiotawia, a otwiera się na inność (Przyłębski 2006: 38).

Dedecius w podobnym duchu mówił w 1993 roku w Krakowie podczas wykładu wygłoszonego na sympozjum „Narody i stereotypy” w Międzynarodowym Centrum Kultury:

Tłumaczenie z języka na język, z tożsamości na tożsamość jest, co prawda niespokojnym, niepewnym, jednak substancjalnym istnieniem pomiędzy możliwościami. Tłumaczenie posiada też wartości pedagogiczne. Oswaja przeciwieństwa. Nierówności sprowadza do wspólnego mianownika. Ćwiczy bezinteresowność, zdolność adaptacji i tolerancji - wszystkie te właściwości, których tak pilnie dziś potrzebujemy (Dedecius 1996: 73-74).

Ponadto w wykładzie pod znamiennym tytułem Partnerstwo $i$ poezja tłumacz, potwierdzając potrzebę kulturowej wspólnoty w duchu tolerancji, stwierdził:

Nie ma dwóch innych, historycznych i duchowych, krajobrazów w Europie, które z powodu swej bliskości i swych różnic byłyby tak bardzo skazane na siebie, i którym tak bardzo jest potrzebne wzajemne wyczucie - jak polski i niemiecki (Dedecius 1996: 83).

Blisko stąd do tematyki dziejowości, podjętej badawczo w kontekście hermeneutyki przez Elżbietę Paczkowską-Łagowską (Paczkowska-Łagowska 2012). W eseju dotyczącym badań historycznych Diltheya, których główną

${ }^{4}$ Podobnie w innym miejscu u Gadamera: „Nawet jeśli przekład wydaje się przedsięwzięciem beznadziejnie deficytowym, w grę wchodzi nie tylko mniejsza czy większa strata, ale także pewien zysk, przynajmniej zysk interpretacyjny, przyrost wyrazistości i jednoznaczności (Gadamer 2010: 321). 
tezą było, że człowiek rozpoznaje siebie w historii, a nie przez introspekcję, autorka pisze:

Dopiero tło dostępnej całości dziejów i kultury [a nie introspekcja odosobnionej i abstrakcyjnej jednostki] [...] pokazuje pełnię bogactwa natury ludzkiej (Paczkowska-Łagowska 2012: 54).

Są to cenne wskazówki dla badacza twórczości Zbigniewa Herberta, w której, jak wiadomo, historia odgrywa doniosłą rolę. Tym istotniejsze będzie właściwe zorientowanie przekładu przez tłumacza, umiejscowienie go w wybranej perspektywie, zwłaszcza jeśli motywacją jego działań jest kontekst historyczny. Dedecius poszedł nawet dalej, poza historię, i zaczął pojmować poezję jako dziedzinę bliską współczesnej mu polityce:

Kto chce działać na rzecz lepszego porozumienia między dwoma tak dalece ciężko doświadczonymi sąsiadami, jak Polska i Niemcy, musi pojmować jako jedno poezję i politykę. Poezja poszukuje prawdy i piękna, które są motywacją do życia, celem polityki zaś dobro ogółu i sprawiedliwość, które przynoszą temu społeczeństwu wolność (Dedecius 2013: 303).

O uwarunkowaniach politycznych konkretnego aktu przekładu pisał z kolei:

Nie łudźmy się, że tłumaczenie literatury pięknej, wierszy czy dzieł naukowych jest czynnością apolityczną; bynajmniej: potrzebne do tego kontakty, wybór, jakość, oddziaływanie - to wszystko ma pośrednio lub bezpośrednio uwarunkowania polityczne (Dedecius 2013: 269).

Problematykę dziejowości podejmował także Gadamer, u którego oznacza ona zdanie sobie sprawy ze wspólnotowego charakteru bycia i ma bezpośredni związek z tradycją. Z tradycją właśnie i z historią związane jest u Gadamera pojęcie Vorurteil, po polsku oddawane jako „przed-sąd” lub - nieco mniej trafnie - „przesąd”. Zgodnie z poglądami Gadamera rozum nie działa w próżni, nie jest bezzałożeniowy, lecz przeciwnie - pełen wyobrażeń pochodzących z kumulujących się doświadczeń przeszłych pokoleń, a więc z historii i tradycji danego kręgu kulturowego; coś jest więc zawsze przez język zało-

5 Tak Przyłębski 2006: 27. 
żone - vorbestimmt (Przyłębski 2006: 160) ${ }^{6}$. Te wszystkie wyobrażenia tworzą swoisty horyzont wyznaczający granicę porozumienia, a co za tym idzie także granicę przekładu, zwłaszcza że dany język, czy to język wyjściowy, czy docelowy, należy zdaniem Gadamera zawsze do sfery wspólnoty. Warunkowane językowo i kulturowo przedsądy wymuszają więc antycypację sensu, projektujące czytanie.

Karl Dedecius wkroczył na ścieżkę przekładowej kariery w końcu lat 50. ubiegłego stulecia mocnym akcentem, mianowicie antologią Lekcja ciszy ${ }^{7}$. Znalazły się w niej trzy wiersze Zbigniewa Herberta (Struna - Die Saite, Nike, która się waha - Nike wenn sie zögert, Napis - Inschrift) i były to pierwsze tłumaczenia poezji tego autora na język niemiecki. Choć wiersze Herberta o tematyce wojennej lub nawiązujące do doświadczeń II wojny światowej, jak trafnie zauważa Katarzyna Krasoń, nie są w Niemczech najchętniej przekładane (Krasoń 2007: 93 i n.), to jednak ze względu na kontekst historyczny trudnego sąsiedztwa po II wojnie światowej i wspomniany program Dedeciusa warto przyjrzeć się bliżej ich przekładom. Karl Dedecius, interpretując debiutancki tomik Herberta, zauważa przede wszystkim związany z okresem powojennym „wielki temat”, czyli wspomnienia, „elegie i epitafia poświęcone poległym, zaginionym ofiarom wojny, światom, które zginęły" (Dedecius 2008: 267 ${ }^{8}$; za jeden $\mathrm{z}$ najpiękniejszych wierszy wojennych $\mathrm{w}$ ogóle uznaje przy tym Nike, która się waha. Istotne jest też to, że przetłumaczonemu wówczas wierszowi Napis Dedecius pozostał wierny - jego zakończenie przywoływał tłumacz nie raz w swoich esejach dotyczących sztuki przekładu. Wykład o znamiennym tytule Tradycja, która nas przybliza (Dedecius 1996: 123-132) zamknął Dedecius cytatem z tego właśnie wiersza, wybierając go na motto dla parających się czynnie i biernie literaturą. Do tych samych wersów w kontekście dziejowości odwołał się tłumacz w innym swoim eseju - Miejsce spotkania, pisząc o walorach polskiej poezji:

najcenniejszą rzeczą, jaką może nam dać polska poezja, jest jej substancja historiozoficzna, jej analizy moralne i odwaga w dokonywaniu niedogmatycznych syntez:

${ }^{6}$ Fragment eseju Gadamera pt. Jak dalece język dyktuje myślenie?

${ }^{7}$ Lektion der Stille, München 1959.

${ }^{8}$ Ponadto Dedecius wyznacza trzy inne kręgi tematyczne: filozofię, mitologię i afirmację przedmiotów codziennego użytku. 
powtarzam wiersz, który chciałbym

przetłumaczyć na sanskryt

lub piramidę:

gdy wyschnie źródło gwiazd

będziemy świecić nocom

gdy skamienieje wiatr

będziemy wzruszać powietrze

(Dedecius 1973: 139).

Dedecius w swoich licznych wypowiedziach o tłumaczeniu podkreślał, jak wielkie znaczenie ma dlań cel pracy tłumacza. Nie dziwi więc wybór akurat tego wiersza i jego niezłomnego zakończenia.

Pytają mnie o pracę, etykę, zamiar i cel działalności tłumacza. [...] Zamiarem i wolą tłumacza jest przyjacielskie przekraczanie mostów, zwalczanie siebie samego, sprowadzanie do wspólnego mianownika różnych pojęć dla tych samych słów i różnych słów dla tych samych pojęć. Celem tłumacza jest [...] skracać odległości (Dedecius 1974: 42).

W tym kontekście metodologicznie odwołać by się można także do dokonań niemieckiej szkoły przekładu, a zwłaszcza Christiane Nord, która rozwinęła teorię skoposu (Nord 2009). Cel translacji jest wedle tej teorii istotniejszy od dokładności przekładu. Byłoby to założenie zgodne ze wspomnianymi wypowiedziami Dedeciusa, a także dawałoby się zilustrować przekładami jego autorstwa. Założeniem tego tłumacza było bowiem zawsze zbliżenie do siebie - w znaczeniu ponownego zbliżenia - kultur polskiej i niemieckiej. Jak wiadomo, celowi temu podporządkował swoją pracę, zwłaszcza od chwili założenia Instytutu w Darmstadt, którego istnienie służyć miało, w skrócie i słowami Dedeciusa-dyrektora, uprawianiu „polonistyki pragmatycznej o szerszej użyteczności społecznej" (Dedecius 1996: 135). Nie byłoby jednak uprawnione powoływanie się na inny element dorobku funkcjonalistów, mianowicie taki, że najczęściej cel tłumaczenia zostaje zdefiniowany w zleceniu tłumaczenia. Dedecius, uznając celowość pracy przekładowej, pisał bowiem jednocześnie, że to sam tłumacz, a nie wydawca czy koniunktura rynkowa, dyktuje założenia $\mathrm{i}$ kieruje swymi wyborami. Zgodnie z tym modus operandi tłumacz dokonywał najpierw wyboru, a potem przekładu z języka polskiego takich utworów, które w latach powojennych, a także dużo później, nadawały się do tego, by zbliżać do 
siebie oba narody, odnosić je do wspólnych korzeni chrześcijańskich tradycji kultury śródziemnomorskiej'. O takim celowym działaniu, osadzonym w szerokim kontekście społecznym, świadczą także słowa ze szkicu zatytułowanego Przyswajanie obcości w przekładzie, w którym Dedecius pisze o odpowiedniości słów, uznając ją za bardziej trafne określenie niż „wierność przekładu”:

Wybieram termin odpowiedniość słów i sensów, gdyż wydaje mi się on bardziej rzeczowy i kompleksowy od często cytowanej wierności przekładu. Wierność jednakże jest pojęciem wątpliwym, podczas gdy odpowiedniość dotyczy wszystkich płaszczyzn naszej egzystencji - społecznej, politycznej, prawnej i ekonomicznej wymaga więc większej odpowiedzialności i jest czymś zobowiązującym (Dedecius 2013: 244-245).

Tak się złożyło, że poezja Herberta nadawała się do wprowadzania w życie opisanego programu Dedeciusa. Jak wiadomo, w Niemczech stała się (jak na poezję) bardzo popularna, m.in. dzięki czytelnym dla Niemców nawiązaniom. Krytycy zwracali bowiem uwagę zwłaszcza na uniwersalne elementy poetyki Pana Cogito, na odwołania do tradycji, kultury europejskiej, łaciński styl, ironię, proporcje, przejrzystość, intelektualizm. Pojawiło się nawet twierdzenie niemieckiej recenzentki, że wiersze te „odpowiadają całkowicie naszemu sposobowi odczuwania świata" ${ }^{10}$. Sam Dedecius widział w Herbercie wychowanka romantyzmu, a we wspomnieniu o nim pisał, że jego śmierć oznaczała stratę dla całej europejskiej kultury. Nie oczekiwał jednocześnie masowej recepcji polskiej poezji, gdyż wiedział, że w opinii niemieckich odbiorców będzie to lektura trudna, wymagająca sporej czytelniczej kompetencji. Tym większym zaskoczeniem stały się wysokie nakłady tomów Herberta w Niemczech (wysokie w porównaniu np. do nakładów wierszy Miłosza), a także dodruki i popularność poety przejawiająca się w licznych omówieniach prasowych i wieczorach autorskich.

Dwa wiersze Herberta - U wrót doliny oraz, przywołane jedynie porównawczo, Przesłuchanie anioła - wybrane tutaj jako przykładowa ilustracja inter-

9 Parafraza słów Dedeciusa z wywiadu udzielonego w 1990 r.: „Die Trauerarbeit, die es von uns zu leisten gilt, besteht nun darin, aus der Fülle der Polnischen Literatur jene Werke auszuwählen, die geignet sind, Deutsche und Polen als europäische Nationen wieder zusammenzubringen, die alten Wurzeln der Gemeinsamkeiten zwischen unseren Völkern wieder bloßzulegen und uns auf die christlichen Traditionen der mediterranen Kultur zu besinnen" (Reif 1991: 136).

${ }^{10}$ Gisela Höngesberg w Bücherei und Bildung, z. 1, s. 19, R. 17, cyt. za: Dedecius 1973: 130. 
pretacji wpisanej w przekład, sytuują się w kontekście historycznym, przy czym pierwszy czytany jest najczęściej jako obraz sądu ostatecznego aluzyjnie zestawionego z doświadczeniem Zagłady, drugi trudniej skojarzyć z konkretnym odniesieniem historycznym, znaleźć w nim można jednak sygnały i wojenne, i powojenne - odnoszące się do doświadczeń systemu totalitarnego. Ze względu na szkicowy i wstępny charakter niniejszego tekstu pogłębiona i pełna interpretacja nie jest tu możliwa, w związku z czym ograniczona została jedynie do kilku kluczowych spostrzeżeń.

W niemieckim przekładzie $U$ wrót doliny dokonanym przez Dedeciusa (Am Tor des Tals - Herbert 2000: 12-15) w pewnym momencie tłumacz stosuje formę nieosobową zamiast osobowej:

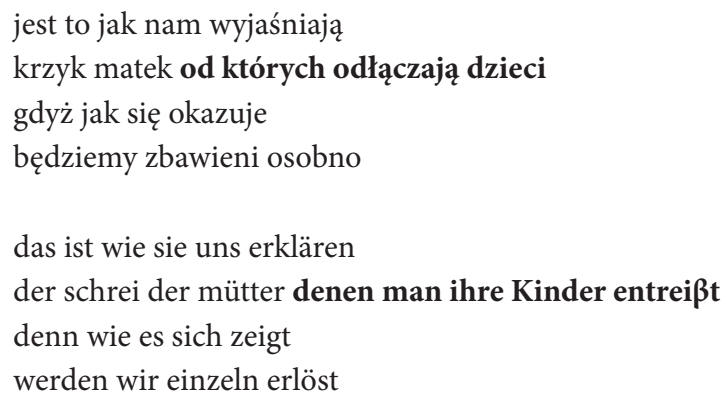

Wydaje się, że nie było zasadniczych przeszkód uniemożliwiających użycie formy osobowej. W podobnej sytuacji, w wierszu Przestuchanie anioła (Das Verhör des Engels - Herbert 2000: 44-47) tłumacz posługuje się bowiem formą osobową:

\section{wieszają go głową w dół}

sie hängen ihn mit dem kopf nach unten

Czyżby użycie formy nieosobowej $\mathrm{w}$ przekładzie pierwszego wiersza wynikało z tego, że wówczas sytuacja i wszelkie jej historyczne konteksty, $\mathrm{w}$ tym te dla niemieckiego czytelnika trudne, ulegają złagodzeniu przez swoiste oderwanie od agensa? A może wręcz przeciwnie, może forma $\mathrm{z}$ „man” powoduje jeszcze większe napięcie przez zestawienie matczynej miłości i rozpaczy z urzędowym, bezosobowym językiem? Tłumacz mógł być świadom tych dysonansów i dlatego być może zdecydował się na brak dosłowności w węzłowym dla utworu miejscu. 
Z jednej strony Dedecius stosuje opisany wieloznaczny zabieg przybliżania-oddalania, ułatwiania-utrudniania niemieckiemu czytelnikowi lektury U wrót doliny, a z drugiej sprawia w swoim przekładzie, że bohaterka wiersza, prosząca:

- schowaj mnie w oku

w dłoni w ramionach

zawsze byliśmy razem

staje się niemieckojęzycznemu odbiorcy wiersza o tyle bliższa, o ile używa jego potocznego, codziennego "doch" - jest to element przez Dedeciusa do trzeciego cytowanego wersu dodany. Po polsku mógłby być oddany jako wzmacniające „przecież” (którego jednak Herbert nie użył):

- verbirg mich im auge

in der hand in den armen

wir waren doch immer zusammen

Przede wszystkim jednak w przekładzie Dedeciusa kobieta nie prosi; ona błaga. Tłumacz używa bowiem czasownika „flehen” zamiast neutralnego „bitten”. W porównaniu z przekładem Przesłuchania anioła w przekładzie U wrót doliny jest zdecydowanie więcej gry na emocjach. Znaleźć można w nim kilka jeszcze miejsc, w których tłumacz to łagodzi, to wzmacnia przekaz.

Być może proponowany klucz lektury, opierający się na tropieniu specyficznych odcieni znaczeniowych, nie jest chybiony, zwłaszcza wobec głównych nurtów interpretacyjnych analizowanego wiersza. Wszak aluzje historyczne są czytelne dla niemieckiego czytelnika, z którego uczuciami tłumacz nie liczy się o tyle, o ile nie ułatwia mu przemknięcia nad tym, co trudne, by dokonało się swoiste katharsis. Wybrany do szkicowej interpretacji przykład uwidacznia więc chociaż w części strategię translatorską Dedeciusa, polegająca na budowaniu mostu służącego nie tylko przeprawie między językami, czyli zrozumieniu, ale i ułatwiającego porozumienie.

\section{Literatura}

Antoniuk, M., 2010, „Rozmowa z Rilkem (i Lewinem). Kilka uwag o nieznanych próbach translatorskich Zbigniewa Herberta", [w:] Język dalekosiężny, M. Heydel, E. Wójcik-Leese, M. Woźniak (red.), Kraków, s. 161-166. 
Dedecius, K., 1989, „Anbau der Philosophie. Zbigniew Herbert auf der Suche nach Selbstgewißheit. In der Höhle der Philosophen. Auflösung der Mythologie. Die Rekonstruktion des Dichters", [w:] tenże, Polnische Profile, Frankfurt am Main, s. 235-286.

Dedecius, K., 2008, Europejczyk z Łodzi. Wspomnienia, tłum. S. Lisiecka, Kraków.

Dedecius, K., 1974, Notatnik tłumacza, tłum. J. Prokop, Kraków.

Dedecius, K., 1996, O Polsce, Europie, literaturze. Dialog przyjaźni, Wrocław.

Dedecius, K., 1973, Polacy i Niemcy. Posłannictwo z książek, tłum. I. i E. Naganowscy, Kraków.

Dedecius, K., 2013, Szkiełko tłumacza i oko poety. Eseje, Kraków.

Gadamer, H.-G., 2000, „Człowiek i język”, tłum. K. Michalski, [w:] tenże, Rozum, słowo, dzieje, Warszawa, s. 52-62.

Gadamer H,-G., 2006, „Jak dalece język dyktuje myślenie?”, [w:] A. Przyłębski, Gadamer, Warszawa.

Gadamer, H.-G., 2009, „Lektura jest przekładem”, tłum. M. Łukasiewicz, [w:] Współczesne teorie przekładu. Antologia, P. Bukowski, M. Heydel (red.), Kraków, s. 321-325.

Gadamer, H.-G., 2007, Prawda i metoda. Zarys hermeneutyki filozoficznej, tłum. B. Baran, Warszawa.

Heidegger, M., 2007, W drodze do języka, tłum. J. Mizera, Warszawa.

Herbert, Z., 2012, „Listy do Heinricha Kunstmanna (1958-1964)”, [w:] Odra, nr 7/8, s. 41-49.

Herbert, Z., 2000, Wiersze. Gedichte, tłum. K. Dedecius, Kraków.

Heydel, M., 2010, „Lot trzmiela, czyli o Herbercie i tłumaczach”, [w:] Język dalekosiężny, M. Heydel, E. Wójcik-Leese, M. Woźniak (red.), Kraków, s. 7-12.

Karl Dedecius und das Deutsche Polen-Institut. Laudationes, Berichte, Interviews, Gedichte. Für Karl Dedecius zum 70. Geburtstag, M. Mack (red.), Darmstadt 1991.

Krasoń, K., 2007, W zwierciadle obcej literatury. Recepcja Zbigniewa Herberta i Tymoteusza Karpowicza w Niemczech, Szczecin.

Lekcja ciszy. Liryka Polska. Lektion der Stille. Polnische Lyrik, wyb., przekł. i wstęp K. Dedecius, oprac. wersji dwujęzycznej i posł. K.A. Kuczyński, Wrocław 2003.

Lekcja ciszy $w$ głosach krytyki niemieckiej. Lektion der Stille. Deutsche Stimmen, tłum. M. Zybura, Wrocław 2009.

Michalski, K., 1998, Heidegger i filozofia wspótczesna, Warszawa.

Nord, Ch., 2009, Wprowadzenie do tłumaczenia funkcjonalnego, [w:] Wspót- 
czesne teorie przekładu. Antologia, P. Bukowski, M. Heydel (red.), Kraków, s. 175-191.

Paczkowska-Łagowska, E., 2012, Człowiek w myśleniu historycznym Wilhelma Diltheya, [w:] taż, O historyczności człowieka. Studia filozoficzne, Gdańsk.

Przyłębski, A., 2006, Gadamer, Warszawa.

Reif, A., 1991, „Wegbreiter der polnischen Literatur in Deutschland”, [w:] Karl Dedecius und das Deutsche Polen-Institut. Laudationes, Berichte, Interviews, Gedichte. Für Karl Dedecius zum 70. Geburtstag, M. Mack (red.), Darmstadt.

Rosinek, V., 1995, „O recepcji w Niemczech”, [w:] Czytanie Herberta, P. Czapliński, P. Śliwiński, E. Wiegandt (red.), Poznań, s. 247-254.

Rymkiewicz, W., 2002, Ktoś i nikt. Wprowadzenie do lektury Heideggera, Warszawa.

Stanaszek, M., W innej formie, w innych oczach. Poezja Zbigniewa Herberta $w$ krajach niemieckojęzycznych, http://www.fundacjaherberta.com/ tworczosc7/bibliografia/pan-cogito-za-granica-polszczyzny/w-innejformie-w-innych-oczach (dostęp: 14 listopada 2013 r.).

Stanaszek, M., Pan Cogito za granica polszczyzny, http://www.fundacjaherberta.com/tworczosc7/bibliografia/pan-cogito-za-granica-polszczyzny (dostęp: 14 listopada 2013 r.).

Schulze, B., 2010, „Niektóre aspekty estetyki indywidualnej Zbigniewa Herberta w przekładach niemieckich i angielskich", [w:] Język dalekosiężny, M. Heydel, E. Wójcik-Leese, M. Woźniak (red.), Kraków, s. 167-177.

Zarychta, P., 2010, „ «Pracuję nad Niemcami, choć to element ciężki». Zbigniew Herbert a niemiecki obszar językowy”, [w:] Język dalekosiężny, M. Heydel, E. Wójcik-Leese, M. Woźniak (red.), Kraków, s. 59-66.

\section{Karl Dedecius' translation programme as an example of the culture-forming role of the translators of Zbigniew Herbert's poetry into German in the context of Hans- Georg Gadamer's hermeneutics}

Summary

The article shows the process of Zbigniew Herbert's poetry "settling down" in the German-speaking countries and in German culture owing to its translations into German. Karl Dedecius as a translator placed Herbert's poetry in a broader context of his own original translation and cultural programme. 
The text also includes references to the correspondence between Herbert and Heinrich Kunstmann. Dedecius' self-comments referring to experiences connected with the translation process, its assumptions and objectives are analysed and interpreted in the hermeneutic context, above all in the context of the output of Hans-Georg Gadamer. Finally, the text is illustrated and enriched by a short draft interpretation of the German translation of Zbigniew Herbert's poem At the Gate of the Valley compared with Preliminary Investigation of an Angel.

Keywords: translation of poetry, literary translation, hermeneutics 
